\title{
Design and Construction of Electronic Vote System in State Polytechnic of Jakarta
}

\author{
Janwari Farqi Saptio, Yoyok S Waluyo \\ Department of Computer and Informatics Engineering \\ State Polytechnic of Jakarta \\ Depok, Indonesia \\ janwari.farqi@gmail.com, yoyok.sw@tik.pnj.ac.id
}

Diterima: 18 September 2015. Disetujui: 20 Oktober 2015. Dipublikasikan: November 2015

\begin{abstract}
Background of many problemis abuse of ballots up to cost in the implementation of election in Indonesia. The vast area of Indonesia was be a reason difficulty of monitoring functions, the amount of funds on each election. Another problem is the lack of voter participant onon election., even though, government have expend a lot funds for that election. The reason of less participant is be caused the length of time to wait or line up in do services and long TPStook place. That matter is a reason why researche tries to build and develop some election application which can be easy to access by all Indonesian public with good secure data as well. This application is easy to use with a single ID for vote like e-KTP, KTM and others. Use this single ID has a purpose to avoid redundancies of data, because Single ID is only for one of characteristic of the owner. The method to build this application uses the Waterfall Model and Extreme Programming model by conducting analysis phase, design phase, implementation phase, testing phase, and evaluation phase. Conclusion of this problem is that by using e-vote or e-election can make easy and up the accelerate of data processs. This article describe to implement the system by making a prototype in the case of PEMIRA in State Polytechnic of Jakarta.
\end{abstract}

Kata Kunci: e-voting, e-ktp, PEMIRA, waterfall, extreme programming, state polytechnic of jakarta

\section{INTRODUCTION}

Increasing the number of voters in 4 last election indicates that democratic process in Indonesia has been running well. Based on data made by the commission since 2004 until 2014 a very high increased data happens that on 2004 total national valid votes 113.462 .414 and election on 2014 national valid votes 124.972 .491 . This means increased 19 million voters within 10 years or increased 9 million voter in 1 election period. By looking at the data then constituency statistic on year 2019 is equal to 132.000 .000 .

The increase in the number of voters will follow with procurement logistic that should be reached to the all voters. Money should be spent from treasury fund for election in 2004 as IDR 2.3 Trillion, 2009 as IDR 6.67 Trillion, and 2014 as IDR 16 Trillion. High fund released due cause to the difficulty to reach the site because Indonesia as an archipelago.

The general election using punched paper media, it is less effective rated from long time, redundancies data, fraudulent ballots and wide range. To solve this, in another side, development of internet in the world, especially in Indonesia, can facilitate the public to voting by online.

PEMIRA in State Polytechnic of Jakarta can be used as a case study which in practices have many problems, from enormous funding problems incurred campus until shortages of ballots box and burglary. With this e-vote data can't be save in conventional ballots box but data can be saved in server which connected to internet and protected the originality data by encryption cryptography process.

As known, cryptography model has been started to developthe use of electronic media. This cryptography technology method can make guarantee secure and accuracy data sent by server. In its application we can use SSL technologies wherein the data submitted will be converted become letter combination and number as well as character from which submitted data can't be read in the event of theft of data on the network.

Objectives of this application development is: How to build and develop an Online apps for EVoting Web Based.

\section{LITERATURE REVIEW}

\section{A. Election}

An election is a formal decision-making process by which a population chooses an individual to hold public office. Elections have been the usual mechanism by which modern representative democracy has operated since the 17 th century [1][2]. Elections may fill offices in the legislative, sometimes in the executive and judiciary, as well as 
for regional and local government. This process is also used in many other private and business organizations, as clubs to voluntary associations and corporations.

The universal use of elections is as a tool for selecting representatives in modern representative democracies [3]. It is in contrast with the practice in the democratic archetype, ancient Athens, where the Elections were considered an oligarchic institution and most political offices filled using sortition, also known as allotment, by which officeholders were chosen by lot [4].

Electoral reform describes the process of introducing fair electoral systems that they are not in place, or improving the fairness or effectiveness of existing systems. Psephology is the study of results and other statistics relating to elections (especially with a view to predicting future results)[5].

To elect means "to choose or make a decision", and so sometimes other forms of ballot such as referendums are referred to as elections, especially in the United States.

\section{B. Website}

Web site, collection of files and related resources are accessible through the World Wide Web and organized under a particular domain name. Typical files found at a web site are called HTML documents with their associated graphic image files (GIF, JPEG, etc.), scripted programs (in Perl, CGI, Java, etc.), and similar resources [6]. The site's files are usually accessed through hypertext or hyperlinks embedded in other files. A web site may consist of a single HTML file, or it may comprise hundreds or thousands of related files. A web site is usual starting point or opening page, called a home page, usually functions as a table of contents or index, with links to other sections of the site.

Web sites are hosted on one or more web servers, which transfer files to client computers or other servers that request them using the HTTP protocol [7]. Although the term "site" implies a single physical location, the files and resources of a Web site may actually be spread among several servers in different geographic locations. The particular file desired by a client is specified by a URL that is either typed into a browser or accessed by selecting a hyperlink.

\section{Electronic ID}

An electronic identification ("eID") is an electronic identification solution of citizens or organizations, for example in view to access benefits or services provided by government authorities, banks or other companies [8]. Apart from online authentication many eICs also give users the option to sign electronic documents with a digital signature.
One form of eID is an electronic identification card, which is a physical identity card that can be used for online and offline personal identification or authentication. The eIC is a smartcard in ID-1 format of a regular bank card, with identity information printed on the surface (such as personal details and a photograph) and in an embedded RFID microchip, similar to that in biometric passports. The chip stores the information printed on the card (such as the holder's name and date of birth) and the holder's biometric photo. It may also store the holder's fingerprints. The card may be used for online authentication, such as for age verification or for e-government applications. An electronic signature, provided by a private company, may also be stored on the chip [9].

Countries which currently issue governmentissued eIDs include Belgium, Bulgaria, Germany, Israel, Italy, Luxembourg, the Netherlands, Mexico, Morocco, Pakistan, Portugal, Romania, Estonia, Latvia, Lithuania, Spain, Slovakia, Malta, and Mauritius. Germany. Previously Finland have accepted government issued physical eIC:s. Norway, Sweden and Finland accepted bank-issued eIDs (also known as BankId) for identification by government authorities [10].

\section{METHOD}

The method used in this article is as follows: Research Method using Waterfall Model. The Waterfall Model was first Process Model introduced. It is also referred to as a linear-sequential life cycle model. It is very simple to understand and use. In a waterfall model, each phase must be completed before the next phase begin and there is no overlapping in the phases. Waterfall model is the earliest SDLC approach used for software development. The waterfall Model illustrates the software development process in a linear sequential flow; hence it is also referred to as a linearsequential life cycle model. This means that any phase in the development process begins only if the previous phase is complete. In waterfall model phases do not overlap [11].

\section{A. Waterfall Model design}

Waterfall approach was first SDLC Model to be used widely in Software Engineering to ensure success of the project. In "The Waterfall" approach, the whole process of software development is divided into separate phases. In Waterfall model, typically, the outcome of one phase acts as the input for the next phase sequentially. The following is a diagrammatic representation of different phases of waterfall model. 


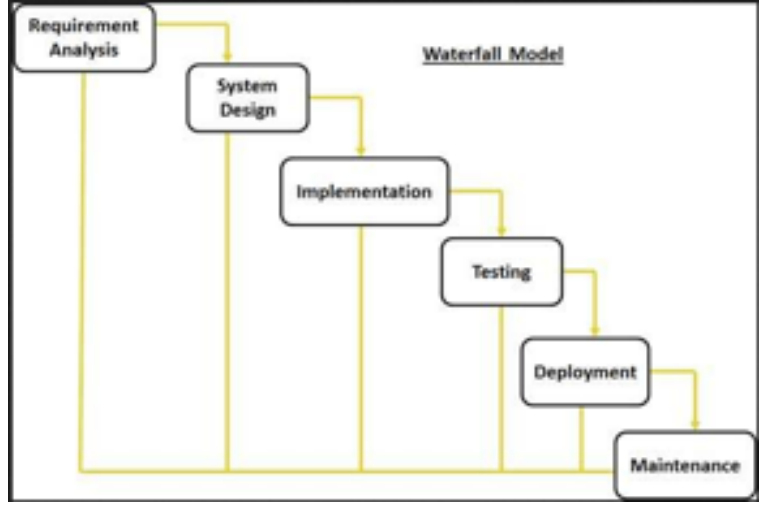

Pic 1. The Sequential Phases in Waterfall Model

- Requirement Gathering and Analysis: All possible requirements of the system to be developed are captured in this phase and documented in a requirement specification doc.

- System Design: The requirement specifications from first phase are studied in this phase and system design is prepared. System Design helps in specifying hardware and system requirements as well as defining overall system architecture.

- Implementation: With inputs from system design, the system is first developed in small programs called units, which are integrated in the next phase. Each unit is developed and tested for its functionality which is referred to as Unit Testing.

- Integration and Testing: All the units developed in the implementation phase are integrated into a system after testing of each unit. Post integration the entire system is tested for any faults and failures.

- Deployment of System: Once the functional and non functional testing is done, the product is deployed in the customer environment or released into the market.

- Maintenance: There are some issues come up in the client environment. To fix those issues patches are released. Also to enhance the product some better versions are released. Maintenance is done to deliver these changes in the customer environment.

All these phases are cascaded to each other in which progress is seen as flowing steadily downwards (like a waterfall) through the phases. The next phase is started only after the defined set of goals are achieved for previous phase and it is signed off, so the name "Waterfall Model". In this model phases do not overlap.

\section{B. Waterfall Model Application}

Every software developed is different and requires a suitable SDLC approach based on the internal and external factors. Some conditions usingappropriate Waterfall model are:

- Requirements are very well documented, clear and fixed.

- Product definition is stable.

- Technology is understood and not dynamic.

- There are no ambiguous requirements.

- Ample resources with required expertise are available to support the product.

- The project is short.

\section{Waterfall Model Pros \& Cons}

\section{1) Advantage}

The advantage of waterfall development is that it allows for departmentalization and control. A schedule can be set with deadlines for each stage of development and a product can proceed through the development process model phases one by one.

Development moves from concept, through design, implementation, testing, installation, troubleshooting, and ends up at operation and maintenance. Each phase of development proceeds in strict order.

\section{2) Disadvantage}

The disadvantage of waterfall development is that it does not allow for much reflection or revision. Once an application is in the testing stage, it is very difficult to go back and change something that was not well-documented or thought upon in the concept stage.

\section{Methods of Implementation}

1. Interview with MPM (Student Consultative Assembly)

This interview is intended for collecting data as analysis needs in this e-vote system development. Interview conducted is to all member of MPM especially Head of MPM to get valid data.

2. Technical Approach to Member of MPM Technical Approach to the member of MPMis intended to help member of MPM to understand process within the E-vote system.

3. Built of prototype to member of MPM test. The aim of this prototype manufacture is to while result presented to trials by all member of MPM and Student senate whether the system is built to suit as expected and is right or not.

\section{E. System Trial}

Testing is to test the system which is online conducted by member of MPM and Student Executive Board from Computer Informatics Engineering. The purpose is to test the system whether it is feasible or not. 


\section{RESULT}

The result obtained from this design and build e-vote system is a web-based system accessed online and only can be used by active student means student of State Polytechnic of Jakarta, especially Computer and Informatics Engineering.

First activity in e-vote system :

1. Student data storage

2. Student Organization data storage

3. Candidate data storage

4. Recapitulation result

5. Choice Activity

6. Vision \& Mission Activity

Counting in this system is using statistic formula to calculate and compare voters data and abstentions data. The formula used is as follows :

$=(($ total suaramasuk $/$ total mahasiswa(per-jurusan $))$

* 100)

That result can compare the state incoming voice this time with all total existing voice.

Formula used to percentage calculation of the vote each candidate is as follows :

Dc $=$ data calon;

ts $=$ total suara

$\mathrm{Dc}=$ Calon

ts $=$ sum(suara_masuk);

Rtotal $=\operatorname{Dc}(\mathrm{ts})$

\section{A. Design User Interface}

The purpose of design is to ease voter candidate and interest to candidate voter. Pics 1-10 show the interface in the system.

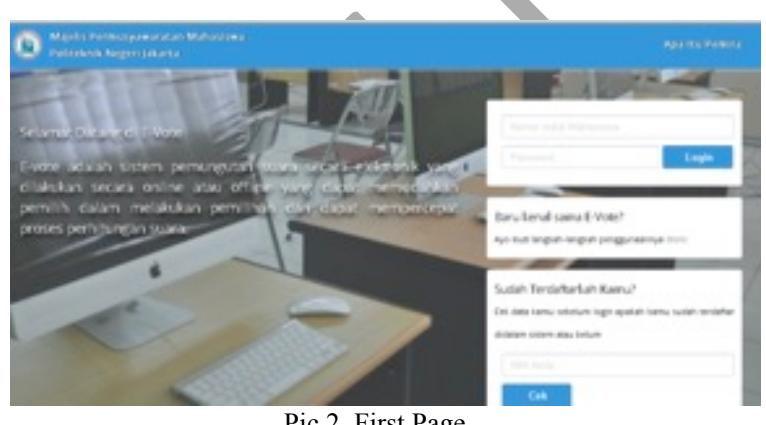

\section{Sudah Terdaftarkah Kamu?}

Cek data kamu sebelum login apakah kamu sudah terdaftar didalam sistem atau belum

4313010036

Cek

Sudah Terdaftarkah Kamu?

Cek data kamu sebelum login apakah kamu sudah terdaftar

didalam sistem atau belum

Anda Terdaftar Dengan identitas

Janwari Farqi Saptio | Angkatan 2613 | Jurusan Teknik Informatika \& Komputer

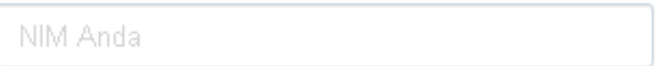

\section{Cek}

Pic 3. Check voters

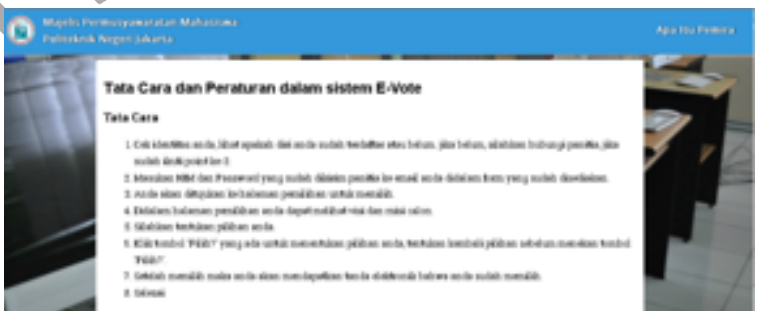

Pic 4. Page How to Use this system

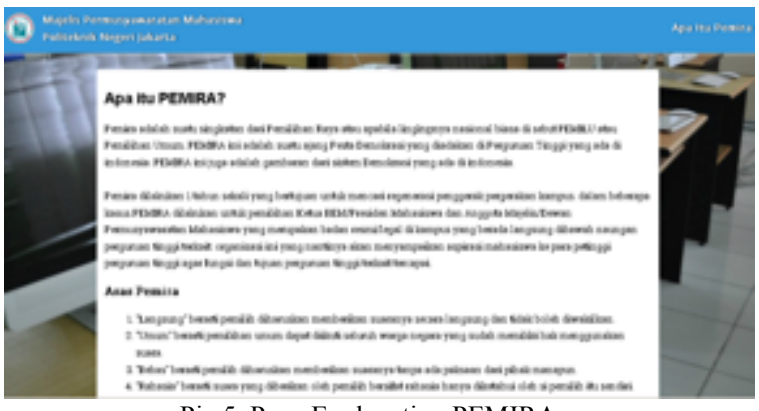

Pic 5. Page Explanation PEMIRA 


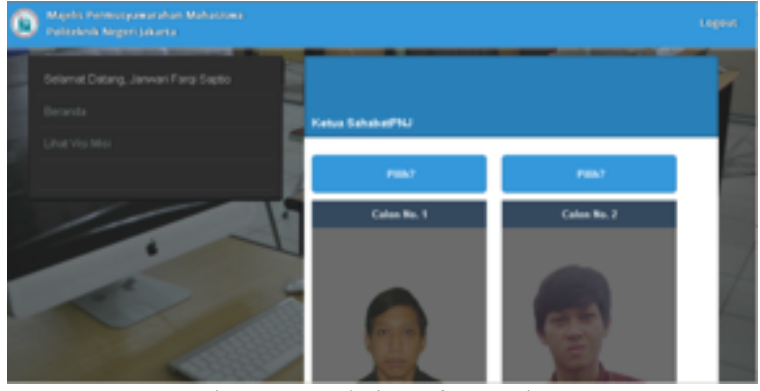

Pic 6. Page Choice After Login

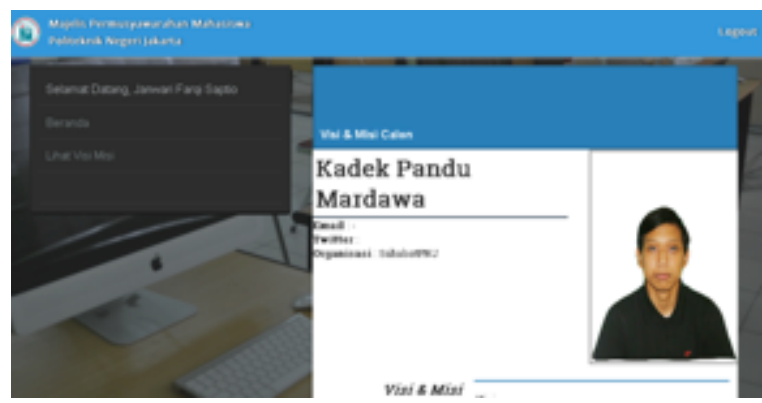

Pic 7. Page Vision and Mission Candidate

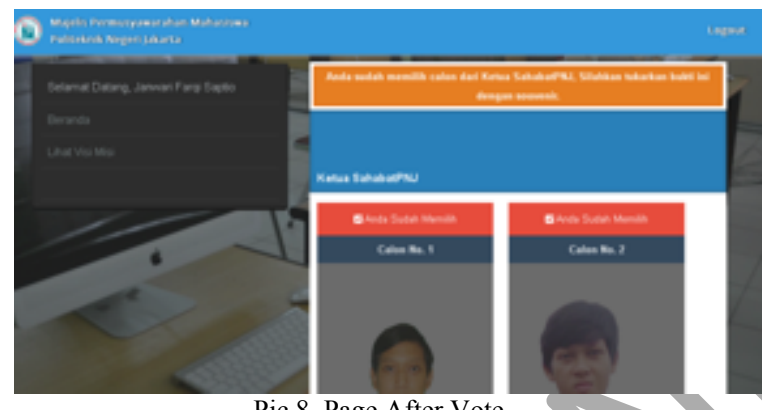

Pic 8. Page After Vote
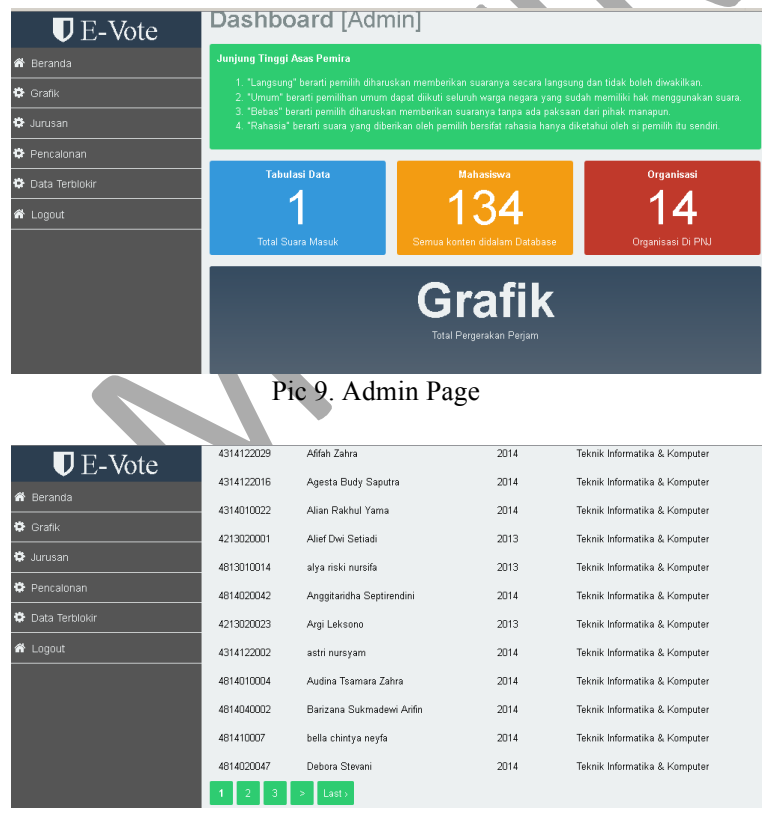

Pic 10. Page Student Storage

This e-vote system gets a great sympathy from students of State Polytechnic of Jakarta, especially Computer and Informatics Engineering students. Byusing Electronic Voting system, student are more interested because this system is easily to access using new technology, fast, and quick along saving paper. This system result gets that more than $65 \%$ voters from 646 student in Computer and Informatics Engineering joined the event.

This result is the highest percentage compared to the other department which using conventional system, using paper which only $54 \%$ maximal voters join the event. This system is also used to protect data with using encryption data in its use. In this system supervisors can see live calculation which conducted by system automatic. Chart movement which conduct per-hours and always move during choose sure it can ease supervisors to oversee this election.

\section{DISCUSSIONS}

In discussions on this e-vote system then it can be found a few problem experienced during the course of this system, they are :

a) This system is very long accessible if it is at busy hour. This matter because a system built still use services data storage from other parties other than that also because lack of found for infrastructure to support system in its application.

b) The user interfaces are less attractive. The use of user interfaces that is less attractive because lack of human resource in development and built the execution system built taking time is very short.

c) Security data Issue are easily damaged. This issue is the most attractive because on election process, security data is the important thing. In few case to security data, researcher have been able handle standard security data.

\section{AWARDS}

In development, this system got a lot of support and awards. The following is an awards received :

a) Support from Head of Department Computer and Informatics Engineering.

b) Support from Head of MPM State Polytechnic of Jakarta the term of office 2014/2015.

c) Support from Head and Member of KSM SahabatPNJ the term of office 2014/2015.

d) Support from extends organization college of Mayday Developer.

e) Support from extends organization college of HIMSISFO Bina Nusantara University.

f) Third Winner of Information System Competition National Level 2015 in Bina Nusantara University. 
g) Support from the ranks of lecturers Department Computer and Informatics Engineering.

\section{CONCLUSION}

Conclusion is that this system can work goes well although with many shortcomings happened. This system is too getting support from many parties that the system must be kept to develop by following current time. The design mske easier, effective and efficient to hold the election.

The election can be done by saving time, money, and reduce unnecessary meetings, meanwhile it does fast and accurate. The design needs validity to verify the detailed info or data mentioned in the system.

\section{REFERENCES}

[1]. Mohammad Kamel Alomari, "Towards E-democracy in the middle east: E-voting adoption." The 9th International Conference for Internet Technology and Secured Transactions (ICITST-2014), 2014, Pages: 73 - 77

[2]. Kausal Malladi, Srivatsan Sridharan, L. T. Jay Prakash, "Architecting a large-scale ubiquitous e-voting solution for conducting government elections.", International Conference on Advances in Electronics Computers and Communications, 2014, Pages: $1-6$

[3]. Manik Hapsara, "E-voting Indonesia: Framing the research.", 9th Iberian Conference on Information Systems and Technologies (CISTI), 2014, Pages: $1-6$

[4]. http://www.britannica.com/topic/election-political-science / diakses tanggal 20 Desember 2015 Pukul 18.08

[5]. Ahmed Hassan; Xiaowen Zhang, "Design and build a secure e-voting infrastructure.", IEEE Long Island Systems, Applications and Technology Conference (LISAT), 2013, Pages: 1 - 7

[6]. Pemungutan Suara Elektronik / https://id.wikipedia.org/ wiki/Pemungutan_suara_elektronik / diakses tanggal 20 September 2015 Pukul $\overline{12.08}$

[7]. Website definition $/$ http://www.webcitation.org/ 6EV535JZ1/ diakses tanggal 21 September 2015 Pukul 21.20

[8]. Silalahi, Bib Paruhun. Bukhari, Fahren dan Nurhudayani, Solikha. 2003. Pengkodean aritmetika untuk kompresi data teks.

[9]. Buono, agus. Ridha, ahmad dan bastian, hanief .2004. Sistem pengenalan wajah real-time dalam ruang eigen dengan segmentasi berdasarkan warna kulit.

[10]. Syadid, muhammad. Hermad, irman dan wijaya, hartono sony. 2004. Penjadwalan perkuliahan menggunakan algoritme genetika.

11]. "sdlc-Waterfall Model" / http://www.tutorialspoint.com /sdlc/sdlc_waterfall_model.htm / 21 December 2015 